Photo receiver silkscreen

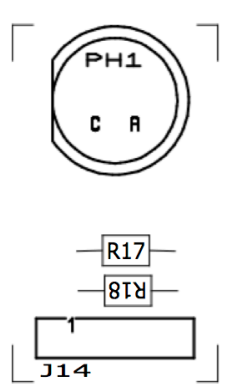

\section{Photo receiver}

solder side

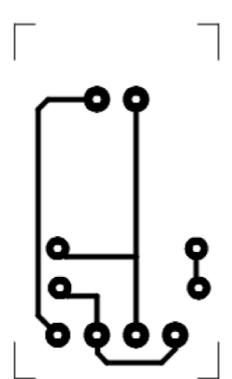

Photo emitter

silkscreen

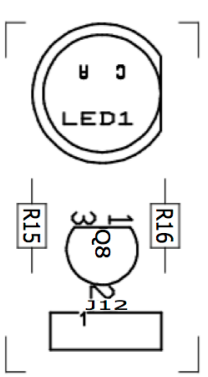

Photo emitter solder side

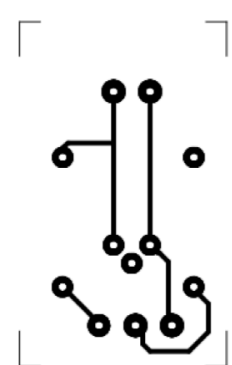

Photo emitter component side

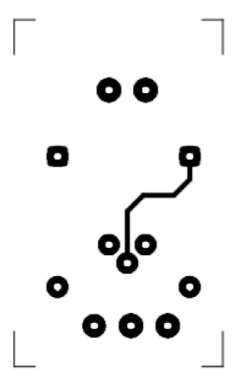

